https://nv.nltu.edu.ua

https://doi.org/10.15421/40281006

Article received 13.11.2018 p.

Article accepted 29.11.2018 p.

\title{
ОСОБЛИВОСТІ СУЧАСНОЇ СТРУКТУРИ НАСАДЖЕНЬ ПАРКУ СЕЛА ПІКІВЕЦЬ
}

Досліджено парк села Піківець Уманського району Черкаської області, якого заклали жителі села та учні школи наприкінці 50-их - початку 60-их років XX ст. Площа парку становить 0,89 га. У парку встановлено пам'ятники учасникам війни 1941-1945 років і жертвам Чорнобильської катастрофи та меморіальний комплекс воїнам-односельцям, які загинули під час Великої Вітчизняної війни, з братською могилою, стелою і "вічним вогнем". Парк має недостатньо розвинуту доріжно-стежкову мережу, яка займає 3,5 \% від загальної площі. Встановлено, що переважаючі види дерев представлені дубом звичайним (Quercus robur L.), липою серцелистою (Tilia cordata Mill.) та гіркокаштаном звичайним (Aesculus hippocastanum L.). Bcraновлено середні показники висот, діаметри стовбурів та крон дерев у деревостанах. У насадженні найбільший середній діаметр стовбура на висоті 1,3 м у представників Quercus robur L. -43 см та Populus piramidalis Rozier - 47,3 см. 3 найбільшим середнім значенням висоти в парку дерева Q. robur L. - 17,4 м, та Populus piramidalis Rozier - 15,3 м. 3'ясовано, що в парку є два типи ландшафтів - парковий $(90 \%)$ та регулярний $(10 \%)$. Проведено розподіл території за виділами, де у 2-му виділі узлісся сформоване з порід, де переважаючими $є$ карагана деревовидна (Caragana arborescens Lam.) та бузок звичайний (Syringa vulgaris L.). Панівним видом у деревостані є дуб звичайний (Quercus robur L.). У 3-му виділі узлісся сформоване з карагани деревовидної (C. arborescens Lam.) з незначною домішкою інших порід. У деревостані немає одного переважаючого виду. Охарактеризовано трав'яний покрив та квіткове оформлення парку.

Ключові слова: парк; видовий склад; висота; діаметр; тип ландшафту; трав'яний покрив.

Вступ. Найголовнішим питанням у використанні існуючих садово-паркових об'єктів, незалежно від часу створення та функціонального призначення, $є$ оцінка їх сучасного стану, загальної декоративності паркових насаджень та території загалом (Shlapak \& Marno-Kutsa 2014).

Мета дослідження - провести інвентаризацію насаджень та встановити сучасний стан та структуру насаджень парку для подальших робіт з їх оптимізації.

Матеріали та методика дослідження. Інвентаризацію проводили, керуючись "Інструкцією з інвентаризації зелених насаджень у населених пунктах України" та методикою комплексної оцінки Клименка (Klimenko \& Kuznetsov, 2014). Назви рослини подано за В. Я. Заячуком (Zaiachuk, 2008), а також за визначником рослин (Dobrochaeva et al., 1987), латинські назви уточнювали за міжнародною класифікацією The Plant List. Для побудови ландшафтного плану застосовували класифікацію ландшафтів Л. І. Рубцова (Rubtsov \& Laptev, 1971), який виділив 6 типів садово-паркового ландшафту: лісовий, парковий, лучний, альпійський, регулярний та садовий. Відповідно до інструкції дерева, за санітарним станом розподіляли на три категорії: добрий, задовільний, незадовільний, а також застосовували методику 3 визначення рівня ураження омелою (Shlapak, Muzyka \& Vitenko, 2011)

Основні результати дослідження. Парк села Піківець Уманського району Черкаської області закладали жителі села та учні школи наприкінці 50-х - початку 60-х років XX ст. біля сільського клубу (Kodzhebash \& Kodzhebash, 2018). Школярі та сільські жителі висаджували дерева та кущі. Територія була огороджена дерев'яним парканом. Площа парку становить 0,89 га. Баланс території наведено у табл. 1. На сьогодні в парку знаходиться пам'ятник учасникам Великої Вітчизняної війни, де встановлено меморіальний комплекс воїнамодносельцям, які загинули під час війни, з братською могилою, стелою та "вічним вогнем", а також пам'ятники учасникам війни 1941-1945 років і жертвам чорнобильської катастрофи (Kodzhebash \& Kodzhebash, 2018).

Табл. 1. Баланс території парку с. Піківець Уманського р-ну (Kodzhebash \& Kodzhebash, 2018)

\begin{tabular}{|c|l|c|c|}
\hline $\begin{array}{c}\text { № } \\
\text { з/п }\end{array}$ & \multicolumn{1}{|c|}{ Назва об'єкта } & $\begin{array}{c}\text { Площа, } \\
\mathbf{m}^{2}\end{array}$ & $\begin{array}{c}\text { Частка від } \\
\text { площі, \% }\end{array}$ \\
\hline 1 & Зелені насадження & 7643 & 85,9 \\
\hline 2 & Доріжки з твердим покриттям & 315 & 3,5 \\
\hline 3 & Будівлі та споруди & 510 & 5,7 \\
\hline 4 & Меморіали & 432 & 4,9 \\
\hline \multicolumn{2}{|c|}{ Всього } & 8900 & 100 \\
\hline
\end{tabular}

3 балансу території бачимо, що в парку недостатньо розвинута доріжно-стежкова мережа, яка займає $3,5 \%$ від загальної площі парку.

Було встановлено видовий склад деревних насаджень. У парку переважають представники покритонасінних, а голонасінні представлені незначною час-

\section{Інформація про автора:}

Коджебаш Анастасія Вадимівна, аспірант, кафедра лісового господарства. Email: anastasiia.vadumivna@gmail.com

цитування за Дсту: Коджебаш А. В. Особливості сучасної структури насаджень парку села Піківець. Науковий вісник Нлту України. 2018, т. 28, № 10. С. 32-35.

Citation APA: Kodzhebash, A. V. (2018). Features of the modern structure of park plantations in the Pikivets village. Scientific Bulletin of UNFU, 28(10), 32-35. https://doi.org/10.15421/40281006 
ткою - лише 3 види (Thuja occibentalis L., Picea abies (L.) H. Karst. та P. pungens Engelm.). Покритонасінні належать до 9 родин, які представлені 20 видами. Видо- вий склад деревних насаджень подано у табл. 2. Кількість кущів, що належать до незлічуваних, тобто зростають куртинами, не зазначено.

Табл. 2. Видовий склад насадження парку с. Піківець

\begin{tabular}{|c|c|c|c|}
\hline \multirow{2}{*}{ Родина } & \multicolumn{2}{|c|}{ Видова назва } & \multirow{2}{*}{ К-ть, шт. } \\
\hline & Українська назва & Латинська назва & \\
\hline \multicolumn{4}{|c|}{ Голонасінні дерева } \\
\hline Кипарисові (Cupressaceae) & Туя західна & Thuja occibentalis L. & 12 \\
\hline \multirow{2}{*}{ Соснові (Pinaceae) } & Ялина звичайна & Picea abies (L.) H. Karst. & 4 \\
\hline & Ялина колюча & Picea pungens Engelm. & 5 \\
\hline \multicolumn{4}{|c|}{ Покритонасінні дерева } \\
\hline Букові (Fagaceae) & Дуб звичайний & Quercus robur L. & 77 \\
\hline Мальвові (Malvaceae) & Липа серцелиста & Tilia cordata Mill. & 54 \\
\hline Вербові (Salicaceae) & Тополя пірамідальна & Populus piramidalis Rozeir & 3 \\
\hline \multirow{3}{*}{ Сапіндові (Sapindaceae) } & Гіркокаштан звичайний & Aesculus hippocastanum L. & 40 \\
\hline & Клен гостролистий & Acer platanoides L. & 8 \\
\hline & Клен-явір & Acer pseudoplatanus L. & 12 \\
\hline \multirow{3}{*}{ Розові (Rosaceae) } & Горобина звичайна & Sorbus aucuparia L. & 1 \\
\hline & Груша звичайна & Pyrus communis L. & 1 \\
\hline & Черешня (вишня пташина) & Cerasus avium (L.) Moench & 1 \\
\hline Бобові (Leguminosae) & Робінія псевдоакація & Robinia pseudoacacia L. & 12 \\
\hline Маслинові (Oleaceae) & Ясен звичайний & Fraxinus excelsior L. & 1 \\
\hline \multicolumn{4}{|c|}{ Покритонасінні кущі } \\
\hline Барбарисові (Berberidaceae) & Магонія падуболиста & Mahonia aquifolium (Pursh) Nutt. & 9 \\
\hline \multirow{2}{*}{ Маслинові (Oleaceae) } & Бузок звичайний & Syringa vulgaris L. & 27 \\
\hline & Бирючина звичайна & Ligustrum vulgaris & 3 \\
\hline \multirow{3}{*}{ Розові (Rosaceae) } & Троянда гібридна & Rosa L. & 9 \\
\hline & Шипшина звичайна & Rosa canina $\mathrm{L}$. & - \\
\hline & Глід шарлоховий & Crataegus coccinea $\mathrm{L}$. & 1 \\
\hline Бобові (Leguminosae) & Карагана дерев'яниста & Caragana arborescens Lam. & - \\
\hline Самшитові (Buxaceae) & Самшит вічнозелений & Buxus sempervirens L. & 4 \\
\hline Сапіндові (Sapindaceae) & Клен татарський & Acer tataricum $\mathrm{L}$. & 1 \\
\hline
\end{tabular}

Підріст переважно однорічний, представлений Acer platanoides L.

У насадженні найбільший середній діаметр стовбура на висоті 1,3 м у представників Quercus robur L. -43 см та Populus piramidalis Rozeir - 47,3 см. Середні показники (діаметри стовбурів на висоті 1,3 м, висоти та діаметри крони) зображено на рис. 1. 3 найвищою середньою висотою в парку є дерева $Q$. robur L. $-17,4$ м та P. Piramidalis Rozeir - 15,3 м.

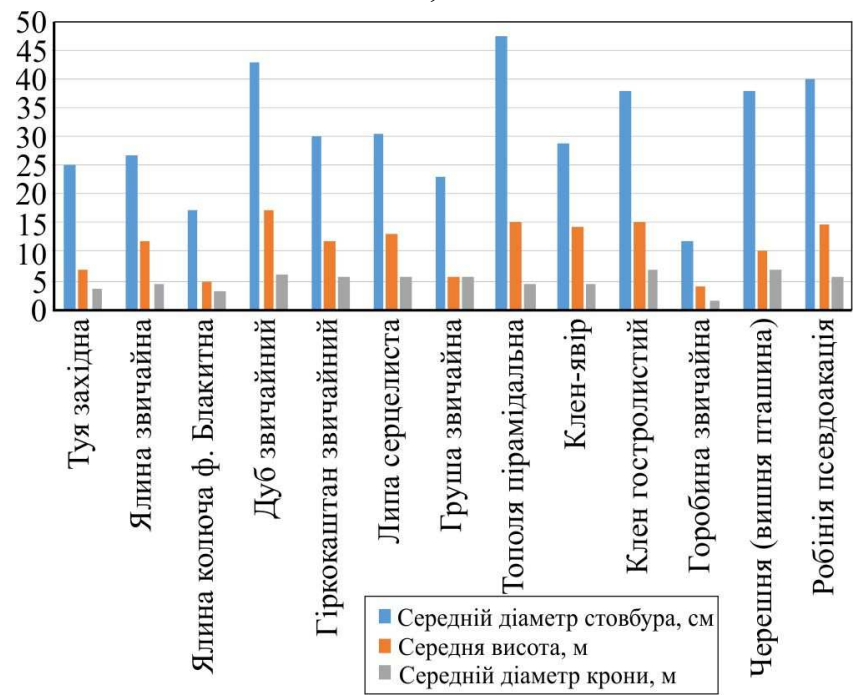

Рис. 1. Середні показники дерев парку с. Піківець

Порівняльно-фітоценотичний аналіз застосовують тільки до певних типів ландшафтів (лісового, паркового та альпійського), тому важливо побудувати ландшафтний план парку (Makarov). На рис. 2 розроблено плансхему розподілу ландшафтів у парку с. Піківець за класифікацією Л. І. Рубцова (Rubtsov \& Laptev, 1971).
У парку (див. рис. 2) ми виділили два типи ландшафту: парковий - $90 \%$ та регулярний - $10 \%$. Водночас усю територію парку доцільно розподілити на три виділи: 1) регулярний, 2) парковий з переважанням дуба звичайного, 3) парковий без переважаючого виду. На рис. 3 подано розподіл території за виділами. У 2-му виділі узлісся має склад деревних порід, де переважаючими є карагана деревовидна та бузок звичайний. Формула деревостану - 5Дзв3Гкз1Лп1Туз+Яле+Ял+ Акб+Яв+Ялк+Гшз. У 3 -му виділі узлісся сформоване 3 карагани деревовидної 3 незначною домішкою інших порід. Формула насаджень у третього виділу така: 3Лпс3Дзв1Гкз1Акб1Яв +Кгл+Гкз+Тп+Грз.

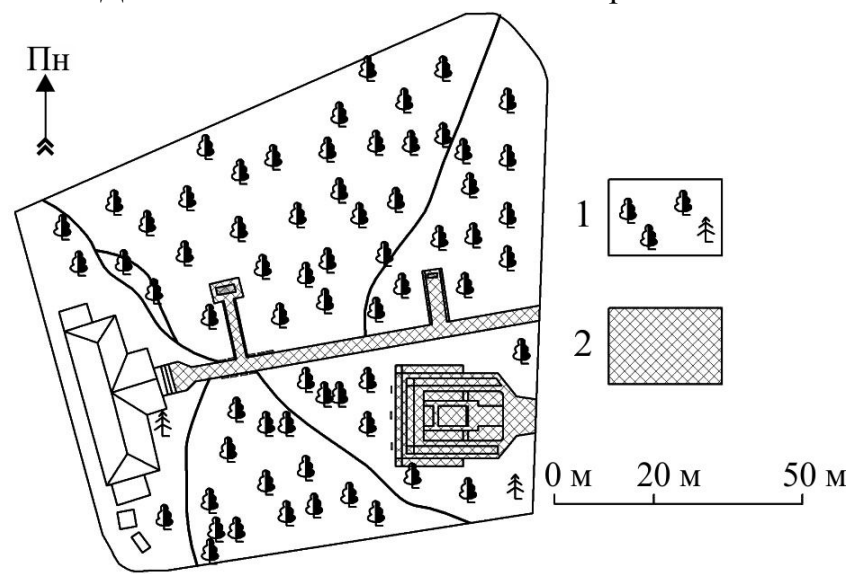

Рис. 2. План-схема розподілу парку за типами ландшафту: 1) парковий тип ландшафту; 2) регулярний тип ландшафту

Санітарний стан більшості дерев оцінено як добрий та задовільний. Незадовільний стан мають 12,8 \% дерев. У парку трапляються сухостійні та суховерхівкові дерева, зі сухими гілками, уражені омелою тощо. Більшість 
дерев Robinia pseudoacacia L. має незадовільний стан. Також Aesculus hippocastanum L. уразила мінуюча міль.

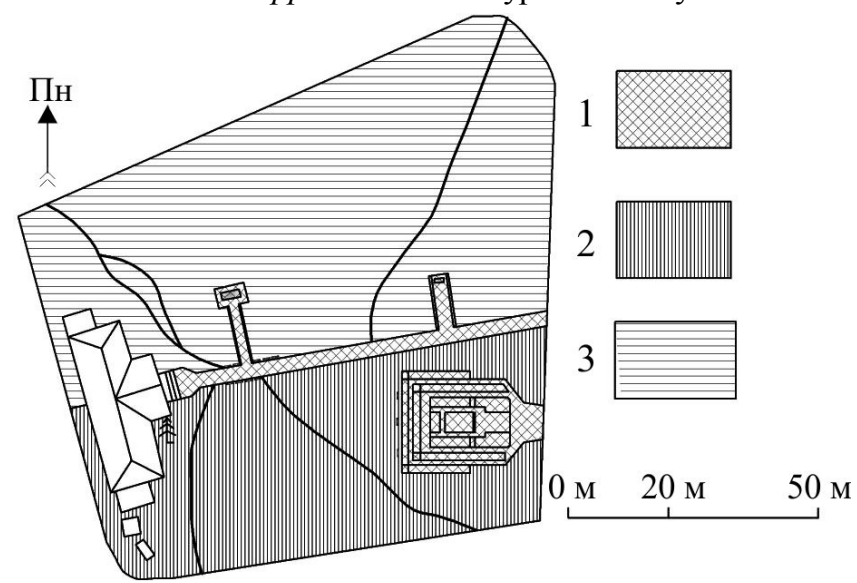

Рис. 3. Розподіл території парку за виділами: виділ 1 - регулярний; 2) виділ 2 - парковий з переважанням дуба звичайного; 3 ) виділ 3 - парковий без переважаючого виду

Трав'яний покрив є нерівномірний. Трав'яниста рослинність представлена такими видами: ряст порожнистий (Corydalis cava (L.) Schweigg. \& Körte), кульбаба лікарська (Taraxacum officinale (L.) Weber ex F. H. Wigg), пирій повзучий (Elymus repens (L.) Gould), волошка синя (Centaurea cyanus L.), подорожник великий (Plantago major L.), кропива глуха стеблообгортна (Lamium amplexicaule L.), кропива жалка (Lamium amplexicaule L.) грицики звичайні (Capsella bursa-pastoris (L.) Medik.), гравілат міський (Geum urbanum L.), фіалка лісова (Viola reichenbachiana Jordanex Boreau), чистотіл лікарський (Chelidonium majus L.), березка польова (Convolvulus arvensis L.), цикорій дикий (Cichorium intybus L.), гірчак повзучий (Acroptilon repens Pall), льнянка звичайна (Linaria vulgaris Milk), синеголовник польовий (Eryngium campestre L.), мишій зелений (Setaria viridis (L.) P. Beauv.), жовтозілля звичайне (Senecio vulgaris L.), петрушка собача (Aethusa cynapium L.), конюшина лучна (Trifolium pratense L.), тощо. На квітниках зростають: іриси (Iris L.), тюльпани (Tulipa L.), волошка синя (Centaurea cyanus L.), лілійник рудуватий (Hemerocallis fulva L.), півонія трав'яна (Peonia $\times$ hybryda hort), ромашка садова (Leucanthemum maximum L.), різні види і сорти очитків (Sedum L.).

\section{Висновки:}

1. Зелені насадження займають 85,9 \% території парку, тоді як доріжки 3 твердим покриттям - 3,5 \%, будівлі та споруди $-5,7 \%$, меморіали $-4,9 \%$.
2. Деревний склад насадження представлений 21 видом, які входять до 11 родин. Голонасінні представлені 3 видами (Thuja occibentalis L., Picea abies (L.) H. Karst., Picea pungens Engelm.).

3. У насаджені найбільший середній діаметр стовбура на висоті 1,3 м у представників дуба звичайного - $43 \mathrm{~cm}$ та тополі пірамідальної - 47,3 см. Найвищими деревами в парку є дуб, робінія псевдоакація і тополя пірамідальна.

4. У парку ми виділили два типи ландшафту - парковий $(90 \%)$ та регулярний $(10 \%)$.

\section{Перелік використаних джерел}

Dobrochaeva, D. N., Kotov, M. I., Prikudin, Iu. N., et al. (1987). Oprededlitel vysshikh rastenii Ukrainy. (1st ed.). Kyiv: Naukova dumka, 548 p. [In Russian].

Instrukcia. (2007). Instruction on inventory of green plantations in settlements of Ukraine. Approved by the Ministry of Construction, Architecture and Housing and Communal Services of Ukraine. (Order number 226 dated 24.12.2001 (with amendments and supplements), 21 p. [In Ukrainian].

Klimenko, Yu. O., \& Kuznetsov, S. I. (2014). Comprehensive evaluation of parkings (methodological approaches and recommendations). Kyiv, 66 p. [In Ukrainian].

Kodzhebash, A. V., \& Kodzhebash, A. P. (2018). Suchasnyi stan parku s. Pikivets. Introduktsiia roslyn na Volyno-Podilli: Science, osvita, mystetstvo formuvannia landshaftu, vyrobnytstvo: Materialy mizhnarodnoi naukovo-praktychnoi konferentsii, (pp. 65-67), May 17-18, 2018. Ternopil. [In Ukrainian].

Markov, F. F., \& Astafieva, V. Ye. (2013). Suchasna struktura nasadzhen parku-pamiatky sadovo-parkovoho mystetstva Vilkhivskyi. (Ser. Lisivnytstvo ta dekoratyvne sadivnytstvo). Scientific reports of the National University of Bioresources and Natural Resources of Ukraine, 187(1), 175-180. [In Ukrainian].

Plant List. (2018). The Plant List. Retrieved from: http://www.theplantlist.org/.

Shlapak, V. P., Muzyka, G. I., \& Vitenko, V. A. (2011). Metodyka vyznachennia stupenya poshkodzhennya derevnykh roslyn Viscum album L. (omeloiu biloiu) ta ii praktychne zastosuvannia. Landshaftna arkhitektura $v$ botanichnykh sadakh $i$ dendroparkakh: Materialy III Mizhnarodnoyi konferentsiyi, (pp. 414-420), June 811, 2011. Kyiv: NBS im. N. N. Hryshka. [In Ukrainian].

Shlapak, V. P., \& Marno-Kutsa, O. Yu. (2014). Kryterii kompleksnoi otsinky suchasnoho stanu ta zberezhenosti istorychnykh parkiv Cherkashchyny. Lisove i sadovo-parkove hospodarstvo, 5. Retrieved from: http://nbuv.gov.ua/UJRN/licgoc_2014_5 13 .

Zaiachuk, V. Ya. (2008). Dendrolohiia. Lviv: Apriori, 410 p. [In Ukrainian].

\section{Уманский начиональный университет садоводства, г. Умань, Украина}

\section{ОСОБЕННОСТИ СОВРЕМЕННОЙ СТРУКТУРЫ НАСАЖДЕНИЙ ПАРКА СЕЛА ПИКОВЕЦ}

Исследован парк села Пиковец Уманского района Черкасской области, который был заложен жителями села и учениками школы в конце 50-х - начале 60-х годов. Площадь парка составляет 0,89 га. В парке установлены памятники участникам войны 1941-1945 годов и жертвам Чернобыльской катастрофы и мемориальный комплекс воинам-односельчанам, погибшим в Великой Отечественной войне с братской могилой, стелой и "вечным огнем". Парк имеет недостаточно развитую дорожно-тропиночную сеть, которая занимает 3,5\% от общей площади. Установлено, что преобладающие виды деревьев представлены дубом обычным (Quercus robur L.), липой сердцелистной (Tilia cordata Mill.) и конским каштаном обыкновенным (Aesculus hippocastanum L.). Установлены средние показатели высот, диаметров стволов и крон деревьев в древостое. В насаждении наибольший средний диаметр ствола на высоте 1,3 м у представителей Quercus robur L. - 43 см и Populus piramidalis Rozier - 47,3 см. С наибольшим средним значением высоты в парке деревья Q. Robur L. - 17,4 м, и Populus piramidalis Rozier - 15,3 м. Установлено, что в парке есть два типа ландшафтов - парковый (90\%) и регулярный (10\%). Проведено распределение территории по выделам, где во 2-м выделе опушки сформированы из пород, где преобладающими являются карагана древовидная (Caragana arborescens Lam.) И сирень обыкновенная (Syringa vulgaris L). Преобладающим видом в древостое является дуб обыкновенный (Quercus robur L.). B 3-м выделе опушки сформированны из караганы древовидной 
(C. arborescens Lam.) C незначительной примесью других пород. В древостое 3-го выдела нет одного преобладающего вида. Охарактеризованы травяной покров и цветочное оформление парка.

Ключевые слова: сад; видовой состав; высота; диаметр; тип ландшафта; травяной покров.

A. V. Kodzhebash

Uman National University of Horticulture, Uman, Ukraine

FEATURES OF THE MODERN STRUCTURE OF PARK PLANTATIONS IN THE PIKIVETS VILLAGE

A park in Pikivets Village of Uman District, Cherkasy Region was founded in 1950th - 1960th by villagers and school children. The assortment of tree plantations in the Park of Pikivets Village was studied. The territory of the park is 0.89 ha. A path system is not ramified enough. Part paths are just $3.5 \%$ of the whole territory. Small architectural forms are represented by monuments, benches, and garbage cans. Two types of landscape (by Rubtsov's classification) can be seen in the Park of Pikivets Village. A plan chart of the park is made. The analysis of the park plantations inventory revealed trees and bushes belonging to twenty-three species and eleven families grown on the territory. A species composition is represented mainly by deciduous trees (twenty species), coniferous trees are represented by three species (Thuja occibentalis L., Picea abies (L.) H. Karst., Picea pungens Engelm.). Quercus robur L., Tilia cordata Mill. and Aesculus hippocastanum L., are the dominant tree species. Populus piramidalis, Acer pseudoplatanus L., Robinia pseudoacacia L. can be seen in the park too. Bushes are represented by Mahonia aquifolium (Pursh) Nutt., Rosa L., Syringa vulgaris L., Caragana arborescens Lam. and other. The highest trees in the park are found to be Quercus robur L. and Populus piramidalis Rozier. Phytosanitary state of many woody plants in the park is not satisfactory. Dry trees and trees with dry branches, trees damaged by Viscum album could be observed there. Herbal cover is studied as well. Corydalis cava (L.) Schweigg. \& Körte, Taraxacum officinale (L.) Weber ex F.H. Wigg, Elymus repens (L.) Gould, Centaurea cyanus L., Plantago major L., Lamium amplexicaule L., Lamium amplexicaule L., Capsella bursa-pastoris (L.) Medik., Geum urbanum L, Viola reichenbachiana Jordanex Boreau, Chelidonium majus L., Convolvulus arvensis L., Cichorium intybus L., Acroptilon repens Pall, Linaria vulgaris Milk, Eryngium campestre L., Setaria viridis (L.) P. Beauv., Senecio vulgaris L., Aethusa cynapium L., Trifolium pretense L., and other can be seen in the park. Flowers are represented by Iris L., Tulipa L., Centaurea cyanus L., Hemerocallis fulva L., Peonia L., Leucanthemum maximum L., Sedum L. Thus, we conclude that green plantations need to be optimized.

Keywords: park; species composition; height; diameter; type of landscape; grass cover. 